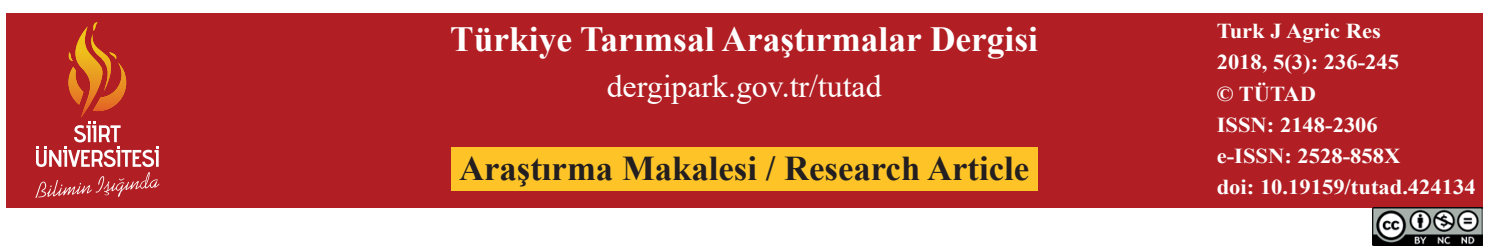

\title{
Bingöl Koşullarında Bazı Burçak [Vicia ervilia (L.) Willd] Genotiplerinin Ot Verimi ve Kalite Özelliklerinin Belirlenmesi
}

\author{
Kağan KÖKTEN ${ }^{1}$, Mahmut KAPLAN² ${ }^{2}$ Seyithan SEYDOŞOĞLU ${ }^{3 *}$, Hava Şeyma YILMAZ \\ Ridvan UCAR \\ ${ }^{1}$ Bingöl Üniversitesi, Ziraat Fakültesi, Tarla Bitkileri Bölümü, Bingöl, TÜRKIYE \\ ${ }^{2}$ Erciyes Üniversitesi, Seyrani Ziraat Fakültesi, Tarla Bitkileri Bölümü, Kayseri, TÜRKIYE \\ ${ }^{3}$ Siirt Üniversitesi, Ziraat Fakültesi, Tarla Bitkileri Bölümü, Siirt, TÜRKIYYE \\ ${ }^{4}$ Kahramanmaraş Sütçü İmam Üniversitesi, Ziraat Fakültesi, Tarla Bitkileri Bölümü, Kahramanmaraş, TÜRKIYE
}

\begin{tabular}{|c|c|}
\hline Gelis Tarihi/Received. 16052018 & Kahul Tarihi/Accented. 11102018 \\
\hline \multicolumn{2}{|l|}{ ORCID ID Vayar surasua ä̈re / bv author order) } \\
\hline \multicolumn{2}{|c|}{ ORCID ID (Yazar strasma göre / by author order) } \\
\hline (1) orcid.org/0000-0001-5403-5629 & \\
\hline
\end{tabular}

*Sorumlu Yazar/Corresponding Author: seyithanseydosoglu@siirt.edu.tr

Öz: Bu çalışmada, Bingöl ekolojik koşullarında yetiştirilen bazı burçak [Vicia ervilia (L.) Willd] genotiplerinin ot verimi ve bazı kalite özelliklerinin belirlenmesi amaçlanmıştır. Araştırma; Bingöl Üniversitesi, Ziraat Fakültesi, Araştırma ve Uygulama arazisinde 2014-2015 yıllarında yazlık yetiștirme sezonunda yürütülmüștür. Araștırmada, 14 adet burçak genotipi (IFVE 248SEL 2785, IFVE 973-SEL 2795, IFVE 2698-SEL 2798, IFVE 2920-SEL 2801 IFVE 3977-SEL 2802, IFVE 3351-SEL 2804, Yerel Lice, D-357, MP, HAT-3, HAT-9, HAT-13, HAT-14 ve HAT-17) bitki materyal olarak kullanılmıștır. Çalıșmada tarla denemesi, tesadüf blokları deneme desenine göre üç tekrarlamalı olarak kurulmuştur. Araştırmada; bitki boyu, yeşil ot verimi, kuru ot verimi, ham kül oranı, ham protein oranı, ham protein verimi, asit deterjanda çözünmeyen lif (ADF), nötral deterjanda çözünmeyen lif (NDF), sindirilebilir kuru madde oranı, kuru madde tüketimi ve nispi yem değeri parametreleri incelenmiştir. Araştırmada sonucunda, bitki boyu dışında incelenen tüm özellikler bakımından genotipler arasında istatistiki olarak $\mathrm{p}<0.05$ ve/veya $p<0.01$ düzeyinde önemli farkl1lıklar belirlenmiștir. İki yıllık araștırma sonucuna göre, kuru ot ve ham protein verimi ile ADF ve NDF oranları dikkate alındığında, IFVE 248-SEL 2785, IFVE 3977-SEL 2802 ve HAT-14 genotiplerinin öne çıktığı; adı geçen bu genotiplerin yörede kaba yem üretimine katkı sağlaması bakımından ivedilikle sslah çalışmalarına alınması önerilmiştir.

Anahtar Kelimeler: Burçak, ot verimi, ot kalitesi, ham protein oranı, genotip

\section{Determination of Herbage Yield and Quality of Some Bitter Vetch [Vicia ervilia (L.) Willd] Genotypes in Bingöl Ecological Conditions}

\begin{abstract}
This research was conducted to determine herbage yield and some quality characteristics of bitter vetch genotypes grown at Bingöl ecological conditions. The study was conducted at the Research and Application fields of Faculty of Agriculture at Bingol University during 2014-2015 summer growing seasons. In the study, 14 different bitter vetch genotypes (IFVE 248-SEL 2785, IFVE 973-SEL 2795, IFVE 2698-SEL 2798, IFVE 2920-SEL 2801 IFVE 3977-SEL 2802, IFVE 3351SEL 2804, Yerel Lice, D-357, MP, HAT-3, HAT-9, HAT-13, HAT-14 ve HAT-17) were used as plant material. The study was conducted according to randomized complete blocks design with 3 replications. In the study, plant height, green herbage yield, dry yield, crude ash ratio, crude protein ratio, crude protein yield, acid detergent fiber (ADF), neutral detergent fiber (NDF), digestible dry matter ratio, dry matter consumption and relative feed value characteristics were investigated. Statistically significant differences were found between the genotypes in all traits examined in the study, except for the plant height. According to the results of two-year research, IFVE 248-SEL 2785, IFVE 3977-SEL 2802 and HAT-14 genotypes were prominent when dry herbage and crude protein yield and ADF and NDF ratios were considered; It has been suggested that these genotypes should be considered in breeding projects to contribute to the forage production of the region.
\end{abstract}




\section{Giriş}

Tarım ve hayvancılığı gelişmiş birçok ülkede yem bitkileri tarımı, hayvansal üretimin vazgeçilmez bir öğesi durumundadır. Türkiye'nin ekolojik özellikleri, her türlü yem bitkileri tür ve çeşitlerinin ekilişi ve üretimine imkan vermesine karşın, yem bitkileri tarımı bir türlü arzulanan düzeye ulaşmamıştır (Uzun, 2008).

Yem bitkileri tarımının çeşitlendirilmesi ve geliştirilmesi Türkiye'de yem açığının kapatılması bakımından çok önemlidir. Gerek çok yıllık, gerekse tek yıllık yem bitkilerinin tarım sistemi içinde yer alması ve nadas yılında tek yıllık baklagil bitkilerinin kullanılmasıyla yem bitkileri üretimi arttırılabilir (Ekiz, 1995; Andiç ve ark. 1996; Al ve Baysal, 1996; Özyazıcı ve Manga, 2000; Turan ve ark., 2015).

Türkiye'de tarım alanlarının büyük bir kısmı kurak ve yarı kurak bölgelerde bulunmaktadır. Bu bölgelerde çayır ve meraların ürettikleri yem miktarları çok düşük ve yetişebilecek yem bitkilerinin çeşitleri de çok fazla değildir. Hububat tarımın esas olduğu bu bölgelerde ekim nöbeti içinde veya dışında kullanılabilecek ve aynı zamanda tanesinden de faydalanilabilecek yem bitkilerinin yetiştirilmesi büyük önem taşımaktadır. Türkiye'nin birçok bölgesinde senelerdir ekilen ve çevreye uyum sağlayabilen yem bitkilerden birisi de burçak [Vicia ervilia (L.). Willd.]'tır. Burçak otundan silaj yapılabilmesi, kışlık yoğun yem olarak kullanılabilmeleri, besleme değerlerinin üstünlüğü, taşıma, depolama ve muhafazalarının daha kolay olması gibi nedenlerle diğer yem bitkileri gibi tercih edilebilir.

$\mathrm{Bu}$ araştırma, Bingöl koşullarında bazı burçak genotiplerinin ot verimi ve kalite özelliklerinin belirlenmesi amaçlanmaktadır.

\section{Materyal ve Yöntem}

Bu araştırma; 2014 ve 2015 yılları yaz yetiştirme döneminde, Bingöl Üniversitesi Ziraat Fakültesi Araştırma ve Uygulama Arazisi'nde yürütülmüştür. Araştırmada, Suriye-Uluslararası Kurak Alanlarda Tarımsal Araştırma Merkezi (ICARDA) orjinli 6 adet, Diyarbakır ve Mardin orjinli 3 adet, Ankara Üniversitesi Ziraat Fakültesi'nden temin edilen 5 adet hat olmak üzere toplam 14 burçak genotipi kullanılmıştır (Tablo 1).

Denemeler kurulmadan önce alınan toprakların bazı fiziksel ve kimyasal özellikleri Tablo 2'de verilmiștir. Buna göre, araştırma alanı topraklarının; tınlı tekstürlü, hafif asit karakterli, tuzsuz, az kireçli olduğu; organik madde kapsamının az, alınabilir fosfor içeriğinin yetersiz ve alınabilir potasyum kapsamının ise yeterli düzeyde olduğu belirlenmiştir (Tablo 2).

Tablo 1. Araştırmada kullanılan materyaller

\begin{tabular}{ll}
\hline Genotipler & Temin edildiği kuruluş \\
\hline IFVE 248-SEL 2785 & ICARDA \\
IFVE 973-SEL 2795 & ICARDA \\
IFVE 2698-SEL 2798 & ICARDA \\
IFVE 2920-SEL 2801 & ICARDA \\
IFVE 3977-SEL 2802 & ICARDA \\
IFVE 3351-SEL 2804 & ICARDA \\
Yerel Lice & Diyarbakır-Lice Popülasyonu \\
D-357 & Diyarbakır Popülasyonu \\
MP & Mardin Popülasyonu \\
HAT-3 & A.Ü.Z.F. \\
HAT-9 & A.Ü.Z.F. \\
HAT-13 & A.Ü.Z.F. \\
HAT-14 & A.Ü.Z.F. \\
HAT-17 & A.Ü.Z.F. \\
\hline
\end{tabular}

A.Ü.Z.F.: Ankara Üniversitesi Ziraat Fakültesi

Tablo 2. Araştırma yeri topraklarının bazı fiziksel ve kimyasal özellikleri $(0-20 \mathrm{~cm})$

\begin{tabular}{lc}
\hline Toprak özelliği & Değeri \\
\hline Suyla doygunluk, \% & 48 \\
pH & 7.22 \\
Tuz içeriği, \% & 0.003 \\
Organik madde, \% & 0.26 \\
Kireç $\left(\mathrm{CaCO}_{3}\right), \%$ & 0.6 \\
Alınabilir potasyum, $\mathrm{kg} \mathrm{K}_{2} \mathrm{O} \mathrm{da}^{-1}$ & 23 \\
Alınabilir fosfor, $\mathrm{kg} \mathrm{P}_{2} \mathrm{O}_{5} \mathrm{da}^{-1}$ & 12.2 \\
\hline
\end{tabular}

Doğu Anadolu Bölgesi'nin Yukarı Firat bölümünde yer alan Bingöl ili, $41^{0} 20^{\prime}$ ve $39^{0} 56^{\prime}$ doğu boylamları ile $39^{\circ} 31^{\prime}$ ve $38^{\circ} \quad 28^{\prime}$ kuzey enlemleri arasındadır. Bingöl ili iklim yönünden ilçelere ve topoğrafik duruma göre değişiklikler göstermektedir. Özellikle Merkez ve Genç ilçelerinde iklim, diğer ilçelere göre oldukça yumuşak geçmektedir. Buna rağmen il genelinde kara iklimi hüküm sürmektedir. Yazları sıcak ve kurak, kışları soğuk ve sert geçen Bingöl'de yağışlar kışın kar halinde, ilkbahar ve sonbahar mevsimlerinde ise yağmur halinde görülmektedir. Çalışmanın yürütüldüğü aylar (Mart, Nisan, Mayıs, Haziran, Temmuz) dikkate alındığında; 2014 vejetasyon döneminde ortalama sicaklık $20.4{ }^{\circ} \mathrm{C}$, toplam yağiș $282.2 \mathrm{~mm}$, ortalama nisbi nem \% 45.0 iken, 2015 döneminde bu değerler sirasıyla $19.2^{\circ} \mathrm{C}$, $251.8 \mathrm{~mm}, \quad \% \quad 42.9$ olmuştur. Uzun yıllar ortalamasına göre vejetasyon dönemindeki ortalama sıcaklık $18.1{ }^{\circ} \mathrm{C}$, toplam yağış $366 \mathrm{~mm}$ ve ortalama nisbi nem \% 48.8 olarak gerçekleşmiştir. Sonuç olarak, Bingöl ilinin 2014 ve 2015 yılları uzun yıllara göre daha az yağışlı ve nemli ve daha sıcak olduğu söylenebilir.

Araștırmada, tarla denemeleri, tesadüf blokları deneme desenine göre 3 tekrarlamalı olarak kurulmuştur. Parsellerde, sıra arası $30 \mathrm{~cm}$ ve her 
parsel 6 sıra olacak şekilde ekim planlanmış olup, parsel alanı $7.2 \mathrm{~m}^{2}$ 'dir. Toprak analizi sonuçları da dikkate alınarak, ekimle birlikte $3 \mathrm{~kg} \mathrm{da}^{-1} \mathrm{~N}$ ve $6 \mathrm{~kg}$ $\begin{array}{llllll}\mathrm{da}^{-1} & \mathrm{P}_{2} \mathrm{O}_{5} & \text { (Diamonyum fosfat, } \% & 43-44 & \mathrm{P}_{2} \mathrm{O}_{5} \text { ) }\end{array}$ olacak şekilde gübreleme yapılmıştır. Ekim işlemi her iki yılda da Nisan ayının ilk haftasında gerçekleştirilmiştir. Hasatta, kenarlardan birer sıra ve parsel başlarından $50 \mathrm{~cm}$ 'lik alan kenar tesiri olarak atılmıştır. Buna göre hasat işlemi; bitkiler \% 50 çiçeklenme döneminde, Haziran ayının son haftasında yapılmıştır.

Hasat edilen parsellerde elde olunan otlar tartılarak parsellerin yaş ot ağırlıkları belirlenmiş, hasat alanı dikkate alınarak her bir parselin dekara yeşil ot verimi tespit edilmiştir. Yeşil ot verimi belirlenen parsellerden tesadüfi olarak alınan 500 g'lık örnekler; $70{ }^{\circ} \mathrm{C}$ 'de sabit ağırlığa gelene kadar kurutulmuş, her parsel için belirlenen kuru ot oranları yeşil ot verimi ile çarpılarak dekara kuru ot verimi hesaplanmıştır (Açıkgöz, 2001). Kuru ot oranı tespit edilen örneklerin ham protein (HP) oranı analizleri Kjeldahl yöntemine göre yapılmıştır (Karaşahin, 2014). Elde edilen kuru ot verimleri HP oranları ile çarpılarak dekara HP verimi hesaplanmıştır (Türk ve ark., 2011). Ham kül (HK) içeriğinin tespiti için ögütülen materyalden $2 \mathrm{~g}$ alınan örnekler kül firınında, $550{ }^{\circ} \mathrm{C}$ de 4 saat (beyaz-gri kül rengi alıncaya kadar) yakılmış ve sonra tartımı yapılarak ham kül oranları belirlenmiştir (Anonymous, 1990). Araştırmada, asit deterjanda çözünmeyen lif oranı (ADF) ve nötral deterjanda çözünmeyen lif oranı (NDF), ANKOM 200 Fiber Analiz yöntemine göre yapılmıştır. Kuru otun; sindirilebilir kuru madde (SKM) ve kuru madde tüketim (KMT) oranları ile nisbi yem değeri (NYD) Eşitlik 1-3 yardımıyla hesaplanmıştır (Morrison, 2003).

$$
\begin{aligned}
& \mathrm{SKM}=88.9-(0.779 \times \% \text { ADF }) \\
& \mathrm{KMT}=120 / \% \mathrm{NDF} \\
& \mathrm{NYD}=(\mathrm{SKM} \times \mathrm{KMT}) / 1.29
\end{aligned}
$$

Araştırmada elde edilen sonuçlar tesadüf blokları deneme desenine göre varyans analizi yapılmış; önemlilik gösteren özelliklere ait ortalamaların karşılaştırılmasında en küçük önemli fark yöntemi (LSD: Least Significant Difference) kullanılmıştır (Kalaycı, 2005).

\section{Bulgular ve Tartışma}

\subsection{Bitki boyu}

Bitki boyu yönünden Tablo 3 incelendiğinde, iki y1llık ortalama verilerine göre; yıl, genotip ve y1l x genotip interaksiyonu istatistiksel olarak önemsiz bulunmuştur. Bununla birlikte; iki yıllık ortalamaya göre, en yüksek bitki boyu $33.0 \mathrm{~cm}$ ile IFVE 3977 SEL 2802 genotipinden elde edilirken, en düşük bitki boyu değeri ise $29.4 \mathrm{~cm}$ ile IFVE 973-SEL 2795 genotipinden elde edilmiştir (Tablo 3).

Bitki boyu ile ilgili olarak farklı ekolojilerde yapılan çalışmalarda, örneğin; Diyarbakır koşullarında burçak bitkisinin bitki boyunun Başbağ ve Gül (2005) 33.25-37.45 cm, Başbağ ve Biçer (2008) 32.29-49.91 cm ve Seydoşoğlu ve ark. (2015) 28.6-39.5 cm, Tokat ekolojik koşullarında Uzun (2008) 16.46-19.37 cm ve Elazığ koşullarında Bakoğlu ve Kökten (2009) 31.23-33.17 cm arasında değişim gösterdiğini rapor etmişlerdir. Bitki boyu

\begin{tabular}{|c|c|c|c|c|c|c|}
\hline \multirow{2}{*}{ Genotipler } & \multicolumn{3}{|c|}{ Bitki boyu (cm) } & \multicolumn{3}{|c|}{ Yeşil ot verimi $\left(\mathrm{kg} \mathrm{da}^{-1}\right)$} \\
\hline & 2014 & 2015 & Ortalama & 2014 & 2015 & Ortalama \\
\hline IFVE 248-SEL 2785 & 32.3 & 32.0 & 32.2 & $444.0 \mathrm{~b}-\mathrm{d}$ & 390.7 g-k & $417.3 \mathrm{de}$ \\
\hline IFVE 973-SEL 2795 & 28.4 & 30.5 & 29.4 & $434.4 \mathrm{c}-\mathrm{f}$ & $358.0 \mathrm{kl}$ & $396.2 \mathrm{e}-\mathrm{g}$ \\
\hline IFVE 2698-SEL 2798 & 29.9 & 31.0 & 30.4 & $384.6 \mathrm{~g}-\mathrm{k}$ & $382.7 \mathrm{~h}-\mathrm{k}$ & $383.6 \mathrm{fg}$ \\
\hline IFVE 2920-SEL 2801 & 32.3 & 32.3 & 32.3 & $411.8 \mathrm{~d}-\mathrm{h}$ & 334.71 & $373.2 \mathrm{~g}$ \\
\hline IFVE 3977-SEL 2802 & 33.2 & 32.8 & 33.0 & $503.7 \mathrm{a}$ & $397.3 \mathrm{f}-\mathrm{j}$ & $450.5 \mathrm{bc}$ \\
\hline IFVE 3351-SEL 2804 & 33.0 & 31.7 & 32.4 & $481.8 \mathrm{ab}$ & $504.0 \mathrm{a}$ & $492.9 \mathrm{a}$ \\
\hline Yerel Lice & 30.5 & 31.0 & 30.8 & $422.1 \mathrm{c}-\mathrm{g}$ & $500.7 \mathrm{a}$ & $461.4 \mathrm{~b}$ \\
\hline D-357 & 29.3 & 32.2 & 30.7 & $363.81-1$ & $390.0 \mathrm{~g}-\mathrm{k}$ & $376.9 \mathrm{fg}$ \\
\hline MP & 29.2 & 31.2 & 30.4 & $398.1 \mathrm{f}-\mathrm{j}$ & $438.0 \mathrm{c}-\mathrm{e}$ & $418.1 \mathrm{de}$ \\
\hline HAT-3 & 28.8 & 33.8 & 31.3 & $393.0 \mathrm{~g}-\mathrm{k}$ & $410.0 \mathrm{~d}-\mathrm{h}$ & $401.5 \mathrm{~d}-\mathrm{f}$ \\
\hline НАТ-9 & 30.2 & 30.2 & 30.2 & $433.6 \mathrm{c}-\mathrm{f}$ & $360.7 \mathrm{j}-1$ & $397.1 \mathrm{e}-\mathrm{g}$ \\
\hline НАТ-13 & 29.7 & 31.7 & 30.7 & $410.4 \mathrm{~d}-\mathrm{h}$ & $395.3 \mathrm{~g}-\mathrm{k}$ & $402.9 \mathrm{~d}-\mathrm{f}$ \\
\hline HAT-14 & 30.0 & 29.8 & 29.9 & $455.8 \mathrm{bc}$ & $400.0 \mathrm{e}-1$ & $427.9 \mathrm{~cd}$ \\
\hline HAТ-17 & 32.1 & 31.2 & 31.6 & $391.4 \mathrm{~g}-\mathrm{k}$ & $368.01-1$ & $379.7 \mathrm{fg}$ \\
\hline Ortalama & 30.6 & 31.6 & & $423.5 \mathrm{a}$ & $402.1 b$ & \\
\hline Değişim katsayısı (\%) & & 6.9 & & & 5.6 & \\
\hline $\mathrm{LSD}_{\mathrm{y} 1}$ & & Ö.D & & & $5.4^{* *}$ & \\
\hline LSD genotip & & Ö.D & & & $26.9^{* *}$ & \\
\hline LSD genotip x yll & & Ö.D & & & $38.0^{* *}$ & \\
\hline
\end{tabular}
değerlerinin literatürdeki bu değerlerden farklı

Tablo 3. Burçak genotiplerinde belirlenen bitki boyu ve yeşil ot verimine ilişkin ortalama değerler

**: Aynı grup içinde aynı harfle gösterilen ortalamalar arasında $\mathrm{p}<0.01$ olasılıkla farklılık yoktur, Ö.D.: Önemli değil 
olması; araştırmanın yürütüldüğü alanın ekolojik özellikleri, ele alınan bitkisel materyalin genetik yapılarının farklı olması ve ekim alanı toprak özelliklerinin farklı olmasından kaynaklanmaktadır.

\subsection{Yeşil ot verimi}

Tablo 3'ten de görüldüğü üzere, yeşil ot verimi yönünden yıllar arasında istatistiksel olarak çok önemli (\% 1) farklılık görülmüştür. Birinci yılda yeşil ot verimi $423.5 \mathrm{~kg} \mathrm{da}^{-1}$ iken, 2015 y1lında ise yeşil ot verimi $402.1 \mathrm{~kg} \mathrm{da}^{-1}$ olarak belirlenmiştir. İkinci y1lda bir miktar yeşil ot verimi düşmüş olup, bunun nedeni olarak 2015 yılındaki yağış miktarının 2014 yılına göre daha düşük olduğu gösterilebilir. Genotipler arasında yeşil ot verimi açısından istatistiksel olarak çok önemli (\% 1) farklılıklar görülmüştür (Tablo 3). İki y1llık ortalamaya göre, en yüksek yeşil ot verimi $492.9 \mathrm{~kg}$ $\mathrm{da}^{-1}$ ile IFVE 3351-SEL 2804 genotipinden elde edilirken, en düşük yeşil ot verimi ise $373.2 \mathrm{~kg} \mathrm{da}^{-1}$ ile IFVE 2920-SEL 2801 genotipinde belirlenmiştir. Genotipler arasındaki bu farklılıklar, genotiplerin genetik yapısından kaynaklandığ 1 düşünülmektedir.

Araştırmanın birinci yılında IFVE 3977-SEL 2802 genotipi istatistiksel olarak en yüksek grubu oluşturan yeşil ot verimi verirken, çalışmanın ikinci yılında ise aynı genotipin yeşil ot verimi veriminde düşüş kaydedilmiş ve istatistiki açıdan farklı grubu oluşturmuştur. Aynı şekilde, Yerel Lice genotipi 2014 yilında $422.1 \mathrm{~kg} \mathrm{da}^{-1}$ ile düşük yeşil ot verimi veren grupta yer alırken, çalışmanın ikinci yılında ise en yüksek verim veren birinci grupta yer almıştır. Genotiplerin farklı yıllarda göstermiş olduğu bu farklı performans sonucunda, genotip x y1l interaksiyonu istatistiksel yönünden çok önemli (\% 1) bulunmuştur (Tablo 3).

Yeşil ot verimi yönünden, yapılan farklı çalışmalarda, Başbağ ve Gül (2005) Diyarbakır koşullarında $1388.8-1642.7 \mathrm{~kg} \mathrm{da}{ }^{-1}$, Ayan ve ark (2006) Samsun koşullarında 618.0-1445.5 kg da-1, Çil ve ark. (2007) Harran Ovası koşullarında 2222.0-2897.0 kg da-1 , Bakoğlu ve Kökten (2009) Elazığ koşullarında 1383.00-1922.05 kg da-1 ve Seydoşoğlu ve ark. (2015) Diyarbakır koşullarında 1613.5-2039.5 kg da $\mathrm{da}^{-1}$ arasında değiştiğini bildirmişlerdir. Literatürlerde rapor edilen bu verilerin çalışmamız sonuçlarıyla farklılık gösterdiği görülmüştür. $\mathrm{Bu}$ farklılıkların nedeni olarak; araştırma alanının iklim (yağış ve sıcaklık gibi) ve toprak (organik madde, tuz, kireç) özelliklerinin, ekim zamanının (yazlık-kışlık) ve kullanılan bitkisel materyallerinin sayısının farklı olması söylenebilir.

\subsection{Kuru ot verimi}

Burçak genotiplerine ait kuru ot verimleri sonuçları incelendiğinde (Tablo 4); yıllar arasında istatistiksel olarak farklılık bulunmazken, kuru ot verimi yönünden araştırmada incelenen genotipler arasında istatistiksel olarak çok önemli ( $\% 1$ 1) farklılık görülmüştür. İki yıllık ortalamaya göre; en yüksek kuru ot verimi istatistiksel olarak birinci grubu oluşturan IFVE 248-SEL $2785 \quad(108.0$ $\left.\mathrm{kg} \mathrm{da}^{-1}\right)$, IFVE 3977-SEL $2802 \quad\left(109.0 \mathrm{~kg} \mathrm{da}^{-1}\right)$ ve

Tablo 4. Burçak genotiplerinde belirlenen kuru ot verimi ve ham protein oranına ilişkin ortalama değerler ${ }^{1}$

\begin{tabular}{|c|c|c|c|c|c|c|}
\hline \multirow{2}{*}{ Genotipler } & \multicolumn{3}{|c|}{ Kuru ot verimi $\left(\mathrm{kg} \mathrm{da}^{-1}\right)$} & \multicolumn{3}{|c|}{ Ham protein oran $1 \%)$} \\
\hline & 2014 & 2015 & Ortalama & 2014 & 2015 & Ortalama \\
\hline IFVE 248-SEL 2785 & $108.1 \mathrm{a}-\mathrm{c}$ & 108.0 a-d & $108.0 \mathrm{a}$ & $16.9 \mathrm{ab}$ & $11.6 \mathrm{j}$ & $14.2 \mathrm{bc}$ \\
\hline IFVE 973-SEL 2795 & $98.2 \mathrm{~b}-\mathrm{g}$ & $97.7 \mathrm{~b}-\mathrm{g}$ & 97.9 bd & $15.1 \mathrm{c}-\mathrm{e}$ & $13.3 \mathrm{~g}-1$ & $14.2 \mathrm{~b}-\mathrm{d}$ \\
\hline IFVE 2698-SEL 2798 & $89.7 \mathrm{f}-1$ & 88.3 g-1 & $89.0 \mathrm{de}$ & $15.3 \mathrm{c}-\mathrm{e}$ & $16.2 \mathrm{bc}$ & $15.8 \mathrm{a}$ \\
\hline IFVE 2920-SEL 2801 & $86.4 \mathrm{~g}-1$ & 77.71 & $82.0 \mathrm{e}$ & $17.5 \mathrm{a}$ & $9.8 \mathrm{k}$ & $13.6 \mathrm{c}-\mathrm{f}$ \\
\hline IFVE 3977-SEL 2802 & $115.3 \mathrm{a}$ & $102.7 \mathrm{a}-\mathrm{f}$ & $109.0 \mathrm{a}$ & $16.2 \mathrm{bc}$ & $10.2 \mathrm{k}$ & $13.2 \mathrm{e}-\mathrm{g}$ \\
\hline IFVE 3351-SEL 2804 & $106.8 \mathrm{a}-\mathrm{d}$ & 107.7 a-d & $107.2 \mathrm{ab}$ & $14.5 \mathrm{ef}$ & $11.6 \mathrm{j}$ & $13.0 \mathrm{fg}$ \\
\hline Yerel Lice & $92.6 \mathrm{e}-\mathrm{h}$ & $115.0 \mathrm{a}$ & $103.8 \mathrm{a}-\mathrm{c}$ & $14.9 \mathrm{de}$ & $13.6 \mathrm{fg}$ & $14.3 \mathrm{bc}$ \\
\hline D-357 & 76.81 & $89.3 \mathrm{f}-1$ & $83.1 \mathrm{e}$ & $16.2 \mathrm{bc}$ & $9.8 \mathrm{k}$ & $13.0 \mathrm{fg}$ \\
\hline MP & $94.1 \mathrm{~d}-\mathrm{h}$ & $89.3 \mathrm{f}-1$ & $91.7 \mathrm{de}$ & $13.2 \mathrm{~g}-1$ & $9.7 \mathrm{k}$ & $11.5 \mathrm{~h}$ \\
\hline HAT-3 & $85.4 \mathrm{~g}-1$ & $95.3 \mathrm{c}-\mathrm{h}$ & $90.4 \mathrm{de}$ & $15.7 \mathrm{~b}-\mathrm{d}$ & $12.1 \mathrm{ij}$ & $13.9 \mathrm{c}-\mathrm{e}$ \\
\hline HAT-9 & $97.1 \mathrm{~b}-\mathrm{h}$ & 83.7 h1 & $90.4 \mathrm{de}$ & $13.4 \mathrm{f}-\mathrm{h}$ & $13.3 \mathrm{f}-\mathrm{h}$ & $13.4 \mathrm{~d}-\mathrm{g}$ \\
\hline HAТ-13 & $92.2 \mathrm{e}-\mathrm{h}$ & $98.3 \mathrm{~b}-\mathrm{g}$ & $95.3 \mathrm{~cd}$ & $16.1 \mathrm{~b}-\mathrm{d}$ & $9.4 \mathrm{k}$ & $12.7 \mathrm{~g}$ \\
\hline НАТ-14 & $110.8 \mathrm{ab}$ & 105.0 a-e & $107.9 \mathrm{a}$ & $16.7 \mathrm{ab}$ & $12.3 \mathrm{~h}-\mathrm{j}$ & $14.5 \mathrm{bc}$ \\
\hline HAT-17 & $84.6 \mathrm{~g}-1$ & $83.3 \mathrm{~h} 1$ & $84.0 \mathrm{e}$ & $17.5 \mathrm{a}$ & $12.4 \mathrm{~g}-\mathrm{j}$ & $14.9 \mathrm{ab}$ \\
\hline Ortalama & 95.6 & 95.8 & & $15.7 \mathrm{a}$ & $11.8 \mathrm{~b}$ & \\
\hline Değişim katsayısı (\%) & & 8.9 & & & 5.4 & \\
\hline LSD yil & & Ö.D. & & & $1.6^{* *}$ & \\
\hline LSD genotip & & $9.8^{* *}$ & & & $0.9^{* *}$ & \\
\hline LSD genotip $x$ yll & & $13.9^{*}$ & & & $1.2^{* *}$ & \\
\hline
\end{tabular}

${ }^{1}$ : Aynı grup içinde aynı harfle gösterilen ortalamalar arasındaki farklılık istatistiki yönden önemli değildir, ${ }^{*}: \mathrm{p}<0.05$ düzeyinde farklılık, ${ }^{* *}: \mathrm{p}<0.01$ düzeyinde önemli farklılık, Ö.D.: Önemli değil 
IFVE 3351-SEL $2804 \quad\left(107.2 \quad \mathrm{~kg} \quad \mathrm{da}^{-1}\right)$ genotiplerinde elde edilirken, adı geçen bu genotiplerin kuru ot verimleri ile Yerel Lice (103.8 $\mathrm{kg} \mathrm{da}^{-1}$ ) ve HAT-14 (107.9 $\left.\mathrm{kg} \mathrm{da}^{-1}\right)$ genotiplerinin kuru ot verimleri arasındaki farklılık istatistiksel olarak önemsiz bulunmuştur. Çalışmada, en düşük kuru ot verimi ise istatistiksel olarak aynı grupta yer alan IFVE 2920-SEL 2801 (82.0 kg da $\left.\mathrm{kg}^{-1}\right)$, D-357 $\left(83.1 \mathrm{~kg} \quad \mathrm{da}^{-1}\right)$ ve HAT-17 $\left(84.0 \quad \mathrm{~kg} \quad \mathrm{da}^{-1}\right)$ genotiplerinde bulunmuştur. Genotipler arasındaki bu farklılık, bitkisel materyallerinin genetik yapılarının farklılığından kaynaklandığı söylenebilir.

Araştırmanın birinci yılında IFVE 3977SEL2802 genotipi istatistiksel olarak en yüksek grubu oluşturan kuru ot verimi verirken, çalışmanın ikinci yılında ise aynı genotipin kuru ot veriminde bir miktar düşüş kaydedilmiş ve istatistiki açıdan farklı grubu oluşturmuştur. Aynı şekilde, Yerel Lice genotipi 2014 y1lında $92.6 \mathrm{~kg} \mathrm{da}$ da $^{-1}$ ile düşük ot verimi veren grupta yer alırken, çalışmanın ikinci yılında ise en yüksek verim veren birinci grupta yer almıştır. Genotiplerin farklı yıllarda göstermiş olduğu bu farklı performans sonucunda, genotip x yıl interaksiyonu istatistiksel açıdan önemli (\% 5) bulunmuştur (Tablo 4).

Kuru ot verimi ile ilgili yapılan farklı çalışmalarda; Başbağ ve Gül (2005) Diyarbakır koşullarında 409.7-471.2 $\mathrm{kg} \mathrm{da}{ }^{-1}$, Ayan ve ark. (2006) Samsun koşullarında 139.1-417.9 kg da-1, Çil ve ark. (2007) Harran Ovası koşullarında 499.7$670.7 \mathrm{~kg} \mathrm{da}^{-1}$, Bakoğlu ve Kökten (2009) Elazı̆ koşullarında 286.79-442.43 $\mathrm{kg} \mathrm{da}^{-1}$ ve Seydoşoğlu ve ark. (2015) Diyarbakır ekolojik koşullarında 422.6-509.3 kg da-1 arasında değiştiğini rapor etmişlerdir. Kuru ot veriminin farklı olmasının nedeni olarak; araştırmada kullanılan hatların genotipik farklılıklarının yanında, denemenin yürütüldüğü ekolojik koşullar özellikle de bitkinin yetişme süresi boyunca düşen yağış ve sıcaklıklar gösterilebilir.

\subsection{Ham protein (HP) oranı}

Tablo 4 incelendiğinde, genotiplerin HP oranına etkisi istatistiksel olarak çok önemli ( $\%$ 1) farklılıklar bulunmuştur. İki yıllık ortalamaya göre, en yüksek HP oranı \% 15.8 ile IFVE 2698-SEL 2798 genotipinde elde edilmiş olup, HAT-17 genotipine ait HP oranı (\% 14.9) aralarındaki farklılık istatistiksel açıdan önemsiz bulunmuştur. En düşük HP oranı ise \% 11.5 ile MP genotipinden elde edilmiştir.

Araştırmada, 2014 yılında HP oranı ortalama \% 15.7 iken, 2015 y1lında HP oranı ise ortalama \% 11.8 olarak bulunmuş; yıllar arasındaki bu farklılık istatistiksel açıdan çok önemli ( $\left.\begin{array}{ll}\% & 1\end{array}\right)$ çıkmıştır (Tablo 4).

Genotip x y1l interaksiyonu istatistiksel açıdan çok önemli ( $\%$ 1) farklılıklar görülmüştür. Araştırmanın birinci yılında IFVE 2920-SEL 2801 genotipi istatistiksel olarak en yüksek grubu oluşturan HP oranı elde edilirken, çalışmanın ikinci yılında ise aynı genotipin HP oranında bir miktar düşüş kaydedilmiş ve istatistiki açıdan farklı grubu oluşturmuştur. Aynı şekilde HAT-14 ve HAT-17 genotipleri 2014 yılında sirasiyla \% 16.7, \% 17.5 ile en yüksek HP oranı veren grupta yer alırken, çalışmanın ikinci yılında ise düşük HP oranı veren farklı grupta yer almıştır.

Burçak bitkisi ile farklı ekolojilerde yapılan çalıșmalarda, HP oranı; İspanya ekolojik şartlarında \% 25.8 (Gonzalez ve Andres, 2003), Harran Ovası koşullarında \% 20.93 (İriadam ve Avcı, 2003) ve İran ekolojik şartlarında \% 26.56 (Sadeghi ve ark., 2009) olarak rapor edilmiş; Uzun (2008) Tokat ekolojik koşullarında burçak bitkisinde HP oranının \% 19.98-26.05 arasında değiştiğini bildirmiştir. Ham protein oranı yönünden araştırmamız bulguları ile literatürler arasındaki farklılığın sebebi olarak; laboratuvar şartlarında kullanılan yöntemin farklı olmasının yanında, araştırmada kullanılan bitkisel materyallerin farklı olmasından kaynaklandığ söylenebilir.

\subsection{Ham protein verimi}

Burçak genotiplerine ait ham protein verimi sonuçları incelendiğinde (Tablo 5), yıllar ve genotipler arasında istatistiksel olarak çok önemli (\% 1) farklılıklar görülmüştür. Araştırmanın birinci yılında HP verimi $14.9 \mathrm{~kg} \mathrm{da}^{-1}$ iken, ikinci yılında $11.3 \mathrm{~kg} \mathrm{da}^{-1}$ olarak tespit edilmiştir. İ ki yıllık ortalamaya göre en yüksek HP verimi $15.7 \mathrm{~kg} \mathrm{da}^{-1}$ HAT-14 genotipinde elde edilmiş olup, bu genotip ile IFVE 248-SEL 2785 (15.4 $\left.\mathrm{kg} \mathrm{da}^{-1}\right)$, IFVE 3977 SEL 2802 (14.6 $\mathrm{kg} \mathrm{da}^{-1}$ ) ve Yerel Lice (14.7 kg da $\left.{ }^{1}\right)$ genotipleri arasındaki farklılık istatistiki yönden önemsiz bulunmuştur. Çalışmada, en düşük HP verimi istatistiksel olarak aynı gruba giren D-357 $\left(10.5 \mathrm{~kg} \mathrm{da}^{-1}\right)$ ve MP $\left(10.6 \mathrm{~kg} \mathrm{da}^{-1}\right)$ genotiplerinde belirlenmiştir (Tablo 5).

Araştırmanın birinci yılında IFVE 248-SEL 2785, IFVE 3977-SEL 2802 ve Hat-14 genotipleri istatistiksel olarak en yüksek grubu oluşturan HP verimi verirken, çalışmanın ikinci yılında ise aynı genotiplerin HP verimleri bir miktar düşüş kaydedilmiş ve istatistiki açıdan farklı grubu oluşturmuştur. Genotiplerin farklı yıllarda göstermiş olduğu bu farklı performans sonucunda, genotip x y1l interaksiyonu istatistiksel açıdan çok önemli (\% 1) bulunmuştur (Tablo 5). 
Tablo 5. Burçak genotiplerinde belirlenen ham protein verimi ve ham kül oranına ilişkin ortalama değerler

\begin{tabular}{|c|c|c|c|c|c|c|}
\hline \multirow{2}{*}{ Genotipler } & \multicolumn{3}{|c|}{ Ham protein verimi $\left(\mathrm{kg} \mathrm{da}^{-1}\right)$} & \multicolumn{3}{|c|}{ Ham kül oranı $(\%)$} \\
\hline & 2014 & 2015 & Ortalama & 2014 & 2015 & Ortalama \\
\hline IFVE 248-SEL 2785 & $18.2 \mathrm{a}$ & $12.5 \mathrm{f}-1$ & $15.4 \mathrm{ab}$ & $9.6 \mathrm{~d}-1$ & $9.7 \mathrm{~d}-\mathrm{h}$ & $9.7 \mathrm{c}-\mathrm{f}$ \\
\hline IFVE 973-SEL 2795 & $14.9 \mathrm{~b}-\mathrm{e}$ & $13.0 \mathrm{~d}-\mathrm{h}$ & $13.9 \mathrm{~b}-\mathrm{d}$ & $10.1 \mathrm{~b}-\mathrm{f}$ & $9.7 \mathrm{~d}-\mathrm{h}$ & $9.9 \mathrm{c}-\mathrm{e}$ \\
\hline IFVE 2698-SEL 2798 & $13.7 \mathrm{~b}-\mathrm{f}$ & $14.3 b-f$ & $14.0 \mathrm{bc}$ & $10.0 \mathrm{~b}-\mathrm{f}$ & $9.5 \mathrm{e}-1$ & $9.8 \mathrm{c}-\mathrm{e}$ \\
\hline IFVE 2920-SEL 2801 & $15.1 \mathrm{~b}-\mathrm{d}$ & 7.61 & $11.3 \mathrm{ef}$ & $10.4 \mathrm{a}-\mathrm{e}$ & 8.61 & $9.5 \mathrm{~d}-\mathrm{f}$ \\
\hline IFVE 3977-SEL 2802 & $18.7 \mathrm{a}$ & $10.51-\mathrm{k}$ & $14.6 \mathrm{ab}$ & $11.0 \mathrm{ab}$ & $10.6 \mathrm{a}-\mathrm{d}$ & $10.8 \mathrm{ab}$ \\
\hline IFVE 3351-SEL 2804 & $15.4 \mathrm{bc}$ & $12.5 \mathrm{f}-1$ & $13.9 \mathrm{~b}-\mathrm{d}$ & $8.7 \mathrm{~h} 1$ & $9.2 \mathrm{f}-1$ & $8.9 \mathrm{f}$ \\
\hline Yerel Lice & $13.8 \mathrm{~b}-\mathrm{f}$ & $15.6 \mathrm{~b}$ & $14.7 \mathrm{ab}$ & $10.1 \mathrm{~b}-\mathrm{f}$ & $10.5 \mathrm{a}-\mathrm{e}$ & $10.3 \mathrm{a}-\mathrm{c}$ \\
\hline D-357 & $12.3 \mathrm{f}-1$ & $8.8 \mathrm{kl}$ & $10.5 \mathrm{f}$ & $9.9 \mathrm{c}-\mathrm{f}$ & $10.5 \mathrm{a}-\mathrm{e}$ & $10.2 \mathrm{~b}-\mathrm{d}$ \\
\hline MP & $12.5 \mathrm{f}-1$ & $8.7 \mathrm{kl}$ & $10.6 \mathrm{f}$ & $9.1 \mathrm{f}-1$ & $10.1 \mathrm{~b}-\mathrm{f}$ & $9.6 c-f$ \\
\hline HAT-3 & $13.4 \mathrm{c}-\mathrm{g}$ & $11.5 \mathrm{~g}-1$ & $12.5 \mathrm{de}$ & $10.7 \mathrm{a}-\mathrm{d}$ & $11.3 \mathrm{a}$ & $11.0 \mathrm{a}$ \\
\hline HAT-9 & $13.0 \mathrm{~d}-\mathrm{h}$ & $11.1 \mathrm{~h}-\mathrm{j}$ & $12.1 \mathrm{ef}$ & $8.9 \mathrm{~g}-1$ & $10.8 \mathrm{a}-\mathrm{c}$ & $9.8 \mathrm{c}-\mathrm{e}$ \\
\hline HAT-13 & $14.8 \mathrm{~b}-\mathrm{e}$ & $9.2 \mathrm{j}-\mathrm{k}$ & $12.0 \mathrm{ef}$ & $10.8 \mathrm{a}-\mathrm{c}$ & 9.5 e-1 & $10.2 \mathrm{~b}-\mathrm{d}$ \\
\hline HAT-14 & $18.5 \mathrm{a}$ & $12.9 \mathrm{e}-\mathrm{h}$ & $15.7 \mathrm{a}$ & $10.3 \mathrm{a}-\mathrm{e}$ & $9.9 \mathrm{c}-\mathrm{g}$ & $10.1 \mathrm{~b}-\mathrm{d}$ \\
\hline HAT-17 & $14.8 \mathrm{~b}-\mathrm{e}$ & $10.31-\mathrm{k}$ & $12.6 \mathrm{c}-\mathrm{e}$ & $8.7 \mathrm{~h} 1$ & $9.7 \mathrm{~d}-\mathrm{h}$ & $9.2 \mathrm{ef}$ \\
\hline Ortalama & $14.9 \mathrm{a}$ & $11.3 \mathrm{~b}$ & & 9.9 & 10.0 & \\
\hline Değişim katsayısı (\%) & & 10.2 & & & 6.6 & \\
\hline LSD $_{\mathrm{y} 1}$ & & $5.1^{* *}$ & & & Ö.D. & \\
\hline LSDgenotip & & $1.5^{* *}$ & & & $0.7^{* *}$ & \\
\hline LSD genotip x yl & & $2.2^{* *}$ & & & $1.1^{* *}$ & \\
\hline
\end{tabular}

**: Aynı grup içinde aynı harfle gösterilen ortalamalar arasında $\mathrm{p}<0.01$ olasılıkla farklılık yoktur, Ö.D.: Önemli değil

Ham protein verimi ile ilgili yapılan farklı çalışmalarda; Ayan ve ark. (2006) Samsun ekolojik şartlarında 17.92-50.35 kg da-1 ve Osmanlı (2014) Kayseri ekolojik şartlarında 17.20-25.99 kg da-1 arasında değiştiğini bildirmişlerdir. Bu farklılık, araştırma yerlerinin iklim koşulları ve toprak özelliklerinin, çevre koşullarında kaynaklanabileceği gibi bitkinin genotipinin farklı olmasından da kaynaklanabilir.

\subsection{Ham kül (HK) oranı}

Tablo 5 'te izleneceği üzere, yılların HK oranına etkisi istatistiksel olarak farklılık bulunmazken, HK oranı yönünden araştırmada incelenen genotipler arasında istatistiksel olarak çok önemli (\% 1) farklılıklar görülmüştür. İki yıllık ortalama sonuçlarına göre; en yüksek HK oranı \% 11.0 ile HAT-3 genotipinde saptanmış olup, adı geçen bu genotip ile IFVE 3977-SEL 2802 (\% 10.8) ve Yerel Lice $(\%$ 10.3) genotipleri arasındaki farklılık istatistiki açıdan önemsiz çıkmıştır. En düşük HK oran1 ise \% 8.9 ile IFVE 3351-SEL 2804 genotipinden elde edilmiştir (Tablo 5).

Araştırmanın birinci yılında IFVE 2920-SEL 2801 genotipi istatistiksel olarak en yüksek grubu oluşturan ham kül oranı verirken, çalışmanın 2015 yılında ise aynı genotipin ham kül oranında bir miktar düşüş kaydedilmiş ve istatistiki yönünden farklı grubu oluşturmuştur. Aynı şekilde, HAT-9 genotipi 2014 yılında \% 8.9 ile düşük ham kül oranı veren grupta yer alırken, çalışmanın ikinci yılında ise en yüksek verim veren birinci grupta yer almıştır. Genotiplerin farklı yıllarda göstermiş olduğu bu farklı performans sonucunda, genotip x yıl interaksiyonu istatistiksel açıdan çok önemli (\% 1) bulunmuştur (Tablo 5).

Ham kül oranı ile ilgili yapılan farklı çalışmalarda; Canbolat ve Bayram (2007) Bursa ekolojik şartlarında \% 3.2-4.7, Uzun (2008) Tokat ekolojik şartlarında \% 3.07-3.70 ve Osmanlı (2014) Kayseri ekolojik şartlarında \% 1.92-4.13 arasında değiştiğini, Sadeghi ve ark. (2009) İran ekolojik şartlarında ise burçak bitkisinin HK oranının \% 3.8 olduğunu bildirmişlerdir. Literatürlerde rapor edilen bu verilerin çalışmamız sonuçlarıyla farklılık gösterdiği görülmüştür. Bu farklılıkların nedeni olarak; laboratuvar ortamında kullanılan cihazların farklılığı, denemelerde kullanılan bitkisel materyallerin farklı olmasından kaynaklandığ söylenebilir.

\subsection{Asit deterjanda çözünmeyen lif (ADF) oranı}

Burçak genotiplerine ait ADF oranı sonuçları incelendiğinde (Tablo 6); y1llar arasında istatistiksel olarak farklılık bulunmazken, ADF oranı yönünden araştırmada incelenen genotipler arasında istatistiksel olarak çok önemli $(\%$ 1) farklılık görülmüştür. İki yıllık ortalamaya verilere göre en düşük ADF oranı \% 23.2 ile IFVE 248-SEL 2785 genotipinden elde edilirken; en yüksek ADF oranı ise istatistiksel olarak birinci grubu oluşturan HAT13 (\% 28.9) genotipinde elde edilmiş, D-357 (\% 27.5) genotipi ile aralarındaki farklılık önemsiz bulunmuştur (Tablo 6).

Araştırmanın birinci y1lında D-357 genotipi istatistiksel olarak düşük grubunu oluşturan ADF oranını verirken, çalışmanın ikinci yılında ise aynı 
Tablo 6. Burçak genotiplerinde belirlenen ADF ve NDF oranına ilişkin ortalama değerler ${ }^{1}$

\begin{tabular}{|c|c|c|c|c|c|c|}
\hline \multirow{2}{*}{ Genotipler } & \multicolumn{3}{|c|}{ ADF oran $1(\%)$} & \multicolumn{3}{|c|}{ NDF oran $1(\%)$} \\
\hline & 2014 & 2015 & Ortalama & 2014 & 2015 & Ortalama \\
\hline IFVE 248-SEL 2785 & $23.0 \mathrm{kl}$ & $23.4 \mathrm{~h}-1$ & $23.2 \mathrm{f}$ & $31.9 \mathrm{e}-\mathrm{h}$ & $28.91-\mathrm{k}$ & $30.4 \mathrm{~d}$ \\
\hline IFVE 973-SEL 2795 & $24.9 \mathrm{c}-1$ & $24.4 \mathrm{e}-1$ & $24.7 \mathrm{~d}-\mathrm{f}$ & $32.3 \mathrm{~d}-\mathrm{g}$ & $29.9 \mathrm{~g}-\mathrm{k}$ & $31.1 \mathrm{~cd}$ \\
\hline IFVE 2698-SEL 2798 & $26.7 \mathrm{~b}-\mathrm{d}$ & $23.31-1$ & $25.0 \mathrm{de}$ & $36.3 \mathrm{ab}$ & $28.0 \mathrm{k}$ & $32.1 \mathrm{bc}$ \\
\hline IFVE 2920-SEL 2801 & $23.7 \mathrm{~g}-1$ & 25.9 b-g & $24.8 \mathrm{de}$ & $31.1 \mathrm{f}-1$ & $30.3 \mathrm{~g}-\mathrm{k}$ & $30.7 \mathrm{~cd}$ \\
\hline IFVE 3977-SEL 2802 & $24.1 \mathrm{f}-1$ & $25.7 \mathrm{c}-\mathrm{g}$ & $24.9 \mathrm{de}$ & $32.1 \mathrm{~d}-\mathrm{h}$ & $28.4 \mathrm{k}$ & $30.3 \mathrm{~d}$ \\
\hline IFVE 3351-SEL 2804 & $24.5 \mathrm{~d}-1$ & $26.1 \mathrm{~b}-\mathrm{f}$ & $25.3 \mathrm{c}-\mathrm{e}$ & $33.4 \mathrm{c}-\mathrm{f}$ & $29.9 \mathrm{~g}-\mathrm{k}$ & $31.6 \mathrm{~b}-\mathrm{d}$ \\
\hline Yerel Lice & $25.3 \mathrm{c}-\mathrm{j}$ & $27.0 \mathrm{bc}$ & $26.1 \mathrm{~b}-\mathrm{d}$ & $36.4 \mathrm{ab}$ & $27.9 \mathrm{k}$ & $32.1 \mathrm{bc}$ \\
\hline D-357 & $25.2 \mathrm{c}-\mathrm{k}$ & $29.7 \mathrm{a}$ & $27.5 \mathrm{ab}$ & $34.8 \mathrm{bc}$ & $34.0 \mathrm{~b}-\mathrm{e}$ & $34.4 \mathrm{a}$ \\
\hline MP & $25.5 \mathrm{c}-1$ & $28.1 \mathrm{ab}$ & $26.8 \mathrm{bc}$ & $34.3 \mathrm{~b}-\mathrm{d}$ & $30.1 \mathrm{~g}-\mathrm{k}$ & $32.2 \mathrm{bc}$ \\
\hline HAT-3 & $25.4 \mathrm{c}-1$ & $25.6 \mathrm{c}-\mathrm{h}$ & $25.5 \mathrm{~cd}$ & $32.7 \mathrm{c}-\mathrm{f}$ & $31.0 \mathrm{f}-\mathrm{j}$ & $31.9 \mathrm{~b}-\mathrm{d}$ \\
\hline HAT-9 & $25.1 \mathrm{c}-\mathrm{k}$ & $25.2 \mathrm{c}-\mathrm{j}$ & $25.2 \mathrm{de}$ & $33.0 \mathrm{c}-\mathrm{f}$ & $29.8 \mathrm{~h}-\mathrm{k}$ & $31.4 \mathrm{~cd}$ \\
\hline НАТ-13 & $29.7 \mathrm{a}$ & $28.1 \mathrm{ab}$ & $28.9 \mathrm{a}$ & $37.7 \mathrm{a}$ & $28.7 \mathrm{jk}$ & $33.2 \mathrm{ab}$ \\
\hline НАТ-14 & $23.1 \mathrm{j}-1$ & $26.7 \mathrm{~b}-\mathrm{e}$ & $24.9 \mathrm{de}$ & $35.0 \mathrm{bc}$ & $28.81-\mathrm{k}$ & $31.9 \mathrm{~b}-\mathrm{d}$ \\
\hline HAT-17 & 22.81 & $24.9 \mathrm{c}-1$ & $23.8 \mathrm{ef}$ & $32.8 \mathrm{c}-\mathrm{f}$ & $28.1 \mathrm{k}$ & $30.4 \mathrm{~d}$ \\
\hline Ortalama & 24.9 & 26.0 & & $33.8 \mathrm{a}$ & $29.6 \mathrm{~b}$ & \\
\hline Değişim katsayısı (\%) & \multicolumn{3}{|c|}{5.4} & \multicolumn{3}{|c|}{4.6} \\
\hline LSD y1l & \multicolumn{3}{|c|}{ Ö.D. } & \multicolumn{3}{|c|}{$2.2^{* *}$} \\
\hline LSD genotip & \multicolumn{3}{|c|}{$1.6^{* *}$} & \multicolumn{3}{|c|}{$1.7^{* *}$} \\
\hline LSD genotip $x$ yll & \multicolumn{3}{|c|}{$2.2^{* *}$} & \multicolumn{3}{|c|}{$2.4^{*}$} \\
\hline
\end{tabular}

genotipin ADF oranında bir miktar yükseliş kaydedilmiş ve istatistiki açıdan en yüksek grubu oluşturmuştur. Genotipin ADF oranı yönünden farklı yıllarda göstermiş olduğu bu farklı performans sonucunda, genotip x y1l interaksiyonu istatistiksel açıdan çok önemli (\% 1) bulunmuştur (Tablo 6).

ADF oranı ile ilgili yapılan çalışmalarda; Bursa ekolojik şartlarında \% $5.7-17.4$ (Canbolat ve Bayram, 2007), Tokat ekolojik şartlarında \% 8.8710.14 (Uzun, 2008), İran ekolojik şartlarında \% 6.26.7 (Seifdavati ve ark. 2013) ve Kayseri ekolojik şartlarında \% 8.10-12.20 (Osmanlı, 2014) arasında değiştiği rapor edilmiştir. ADF oranının farklı olması, denemenin yürütüldüğü alanın toprak ve ekolojik koşullarının yanında, denemede kullanılan bitkisel materyallerin farklı olması, laboratuvar ortamında kullanılan yöntemlerin farklı olmasından kaynaklandığı söylenebilir.

\subsection{Nötral deterjanda çözünmeyen lif (NDF) oranı}

Araștırmada ele alınan 14 farklı burçak genotiplerinin NDF oranları yönünden incelendiğinde; yıllar ve genotipler arasında istatistiksel olarak çok önemli ( $\% 11)$ farkl1lık görülmüştür. Birinci yılda NDF oranı \% 33.8 iken, 2015 yılında ise NDF oranı \% 29.6 olarak tespit edilmiştir. İki yıllık ortalamaya verilere göre; en düşük NDF oranı istatistiksel olarak aynı gruba giren IFVE 248-SEL 2785 (\% 30.4), IFVE 3977-

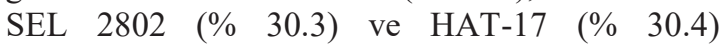
genotiplerinden elde edilmiştir. En yüksek NDF oranı ise D-357 (\% 34.4) genotipinde saptanmış, bu genotip ile HAT-13 (\% 33.2) genotipi arasındaki farklılık istatistiki yönden önemsiz bulunmuştur (Tablo 6).

Genotip x yıl interaksiyonu istatistiksel açıdan önemli (\% 5) bulunmuş olup, genotiplerin farklı yıllarda farklı performans elde edilmiştir (Tablo 6). Araştırmanın birinci y1lında HAT-13 genotipi istatistiksel olarak en yüksek grubu oluşturan NDF oranını verirken, çalışmanın ikinci yılında ise aynı genotipin NDF oranında düşüş gözlemlenmiş ve istatistiki açıdan farklı grubu oluşturmuştur (Tablo 6).

NDF oranı ile ilgili yapılan farklı çalıșmalarda, Canbolat ve Bayram (2007) Bursa ekolojik koşullarında \% 11.5-29.5, Uzun (2008) Tokat ekolojik koşullarında \% 27.44-34.63 ve Osmanlı (2014) Kayseri ekolojik koşullarında \% 25.1532.76 arasında değiştiğini rapor etmişlerdir.

\subsection{Sindirilebilir kuru madde (SKM) oranı}

Burçak genotiplerine ait iki yıllık SKM oranları incelendiğinde (Tablo 7); yılların sindirilebilir kuru madde oranına etkisi istatistiksel olarak önemsiz bulunurken, genotiplerin SKM oranına etkisi istatistiksel olarak önemli (\% 5) çıkmıştır. İki yıllık ortalama verilere göre; en yüksek SKM oranı $\% 70.8$ ile IFVE 248-SEL 2785 genotipinde belirlenmiş olup, ad1 geçen bu genotipe ait SKM oranı ile IFVE 973-SEL 2795 (\% 69.7) ve HAT-17 (\% 70.3) genotiplerinin SKM oranları arasındaki farklılık istatistiksel açıdan önemsiz bulunmuştur. Çalışmada, en düşük SKM oranı ise \% 66.4 ile HAT-13 genotipinden elde edilmiştir (Tablo 7). 
Tablo 7. Burçak genotiplerinde belirlenen SKM ve KMT oranına ilişkin ortalama değerler ${ }^{1}$

\begin{tabular}{|c|c|c|c|c|c|c|}
\hline \multirow{2}{*}{ Genotipler } & \multicolumn{3}{|c|}{ SKM oran1 $(\%)$} & \multicolumn{3}{|c|}{ KMT oran1 $(\%)$} \\
\hline & 2014 & 2015 & Ortalama & 2014 & 2015 & Ortalama \\
\hline IFVE 248-SEL 2785 & $71.0 \mathrm{ab}$ & 70.7 a-e & $70.8 \mathrm{a}$ & $3.8 \mathrm{~d}-\mathrm{h}$ & $4.2 \mathrm{a}-\mathrm{c}$ & $4.0 \mathrm{a}$ \\
\hline IFVE 973-SEL 2795 & $69.5 \mathrm{a}-\mathrm{j}$ & 69.9 a-h & $69.7 \mathrm{a}-\mathrm{c}$ & $3.7 \mathrm{f}-1$ & $4.0 \mathrm{~b}-\mathrm{e}$ & $3.9 \mathrm{a}-\mathrm{c}$ \\
\hline IFVE 2698-SEL 2798 & $68.11-\mathrm{k}$ & $70.8 \mathrm{a}-\mathrm{d}$ & $69.4 \mathrm{bc}$ & $3.3 \mathrm{kl}$ & $4.3 \mathrm{a}$ & $3.8 \mathrm{a}-\mathrm{c}$ \\
\hline IFVE 2920-SEL 2801 & $70.4 \mathrm{a}-\mathrm{f}$ & $68.7 \mathrm{f}-\mathrm{k}$ & $69.6 \mathrm{bc}$ & $3.9 \mathrm{~d}-\mathrm{g}$ & $4.0 \mathrm{c}-\mathrm{f}$ & $3.9 \mathrm{ab}$ \\
\hline IFVE 3977-SEL 2802 & $70.2 \mathrm{a}-\mathrm{g}$ & $68.9 \mathrm{f}-\mathrm{j}$ & $69.5 \mathrm{bc}$ & $3.7 \mathrm{e}-1$ & $4.2 \mathrm{a}-\mathrm{c}$ & $4.0 \mathrm{a}$ \\
\hline IFVE 3351-SEL 2804 & $69.8 \mathrm{a}-1$ & $68.5 \mathrm{~g}-\mathrm{k}$ & $69.2 \mathrm{~b}-\mathrm{d}$ & $3.6 \mathrm{~g}-\mathrm{j}$ & $4.0 \mathrm{~b}-\mathrm{e}$ & $3.8 \mathrm{a}-\mathrm{c}$ \\
\hline Yerel Lice & $69.2 \mathrm{c}-\mathrm{j}$ & $67.9 \mathrm{jk}$ & $68.6 \mathrm{c}-\mathrm{e}$ & $3.3 \mathrm{kl}$ & $4.3 \mathrm{a}$ & $3.8 \mathrm{a}-\mathrm{c}$ \\
\hline D-357 & $69.3 \mathrm{~b}-\mathrm{j}$ & 65.71 & $67.5 \mathrm{ef}$ & $3.51-1$ & $3.5 \mathrm{~h}-\mathrm{k}$ & $3.5 \mathrm{~d}$ \\
\hline MP & $69.0 \mathrm{~d}-\mathrm{j}$ & $67.0 \mathrm{kl}$ & $68.0 \mathrm{de}$ & $3.5 \mathrm{~h}-\mathrm{k}$ & $4.0 \mathrm{c}-\mathrm{f}$ & $3.8 \mathrm{bc}$ \\
\hline HAT-3 & $69.1 \mathrm{~d}-\mathrm{j}$ & $69.0 \mathrm{e}-\mathrm{j}$ & $69.0 \mathrm{~cd}$ & $3.7 \mathrm{~g}-\mathrm{j}$ & $3.9 \mathrm{~d}-\mathrm{g}$ & $3.8 \mathrm{bc}$ \\
\hline НАТ-9 & 69.3 b-j & $69.2 \mathrm{c}-\mathrm{j}$ & $69.3 \mathrm{bc}$ & $3.6 \mathrm{~g}-\mathrm{j}$ & $4.0 \mathrm{a}-\mathrm{d}$ & $3.8 \mathrm{a}-\mathrm{c}$ \\
\hline HAT-13 & 65.71 & $67.0 \mathrm{kl}$ & $66.4 \mathrm{f}$ & 3.21 & $4.2 \mathrm{a}-\mathrm{c}$ & $3.7 \mathrm{~cd}$ \\
\hline HAT-14 & 70.9 a-c & $68.1 \mathrm{~h}-\mathrm{k}$ & $69.5 \mathrm{bc}$ & $3.4 \mathrm{j}-1$ & $4.2 \mathrm{a}-\mathrm{c}$ & $3.8 \mathrm{a}-\mathrm{c}$ \\
\hline HAT-17 & $71.1 \mathrm{a}$ & $69.5 \mathrm{a}-\mathrm{j}$ & $70.3 \mathrm{ab}$ & $3.7 \mathrm{~g}-\mathrm{j}$ & $4.3 \mathrm{ab}$ & $4.0 \mathrm{a}$ \\
\hline Ortalama & 69.5 & 68.6 & & $3.6 \mathrm{~b}$ & $4.1 \mathrm{a}$ & \\
\hline Değişim katsayısı (\%) & & 1.5 & & & 4.5 & \\
\hline LSD yil & & Ö.D. & & & $0.2^{*}$ & \\
\hline LSD genotip & & $1.2^{*}$ & & & $0.2^{*}$ & \\
\hline LSD genotip $x$ yll & & $1.7^{* *}$ & & & $0.3^{* *}$ & \\
\hline
\end{tabular}

Sindirilebilir kuru madde oranı ADF oranı yardımıyla tespit edildiğinden, genotiplerin ADF oranı yönünden farklılık göstermesi SKM oranlarının da farklı olmasında etkili olmuştur.

Araştırmanın birinci yılında HAT-14 genotipi istatistiksel olarak en yüksek grubu oluşturan SKM oranını verirken, çalışmanın ikinci yılında ise aynı genotipin SKM oranında düşüş meydana gelmiş olup, istatistiki açıdan farklı grubu oluşturmuştur. Genotiplerin farklı yıllarda göstermiş olduğu bu farkl1 performans sonucunda, genotip $\mathrm{x}$ y1l interaksiyonu istatistiksel açıdan çok önemli (\% 1) bulunmuştur (Tablo 7).

Bazı baklagil yem bitkileri ile yapılan çalışmalarda, örneğin; Bingöl ekolojik koşullarında Karaköse (2018) SKM oranının ortalama \% 67.0 olduğunu, aynı koşullarda Çaçan ve ark. (2015) bitkilerde SKM oranının \% $53.5-73.8$ arasında değiştiğini rapor etmişlerdir. Sindirilebilir kuru madde oranı yönünden literatürlerle olan bu farklılıklar, araştırmada kullanılan çeşitlerin ve bu çeşitlere ait ADF oranlarının farklı olmasından kaynaklanması ile açıklanabilir.

\subsection{Kuru madde tüketim (KMT) oranı}

Tablo 7'den de izleneceği gibi, KMT oranları yönünden yıllar ve genotipler arasında istatistiksel olarak önemli (\% 5) farklılıklar bulunmuştur. Araştırmanın birinci yılı KMT oranı \% 3.6 iken, 2015 yilında ise bu oran $\% 4$. 1 olarak belirlenmiştir. Kuru madde tüketim oranı NDF oranına bağlı olarak tespit edilen bir özellik olduğundan, yıllar arasında genotiplerin NDF oranlarının değişiklik göstermesi KMT oranlarının da değişim göstermesine neden olmuştur. İki y1llık ortalama sonuçlar incelendiğinde; en yüksek KMT oranı (\% 4.0) istatistiksel olarak birinci grubu oluşturan IFVE 248-SEL 2785, IFVE 3977-SEL 2802 ve HAT-17 genotiplerinden elde edilmiş, adı geçen bu genotiplere ait KMT oranı değerleri ile D-357, MP, HAT-3 ve HAT-13 genotipleri dışındaki diğer genotiplerin KMT oranları arasındaki farklılık istatistiksel olarak önemsiz bulunmuştur. En düşük KMT oranı ise D-357 (\% 3.5) genotipinden elde edilmiştir (Tablo 7).

Araştırmanın birinci yılında HAT-13 genotipi istatistiksel olarak en yüksek grubu oluşturan KMT oranını verirken, çalışmanın ikinci yılında ise aynı genotipin KMT oranında azalma meydana gelmiş ve istatistiksel olarak farklı bir grubu oluşturmuştur. Genotipin farklı yıllarda göstermiş olduğu bu farklı performans sonucunda, genotip x yıl interaksiyonu istatistiksel olarak çok önemli ( $\%$ 1) bulunmuştur (Tablo 7).

Kuru madde tüketim oranı yönünden yapılan bazı çalışmalarda (Çaçan ve ark. 2015; Karaköse, 2018) da benzer bulgular elde edilmiştir.

\subsection{Nispi yem değeri (NYD)}

Burçak genotiplerine ait nispi yem değerleri sonuçları incelendiğinde (Tablo 8); yıllar ve genotipler arasında NYD yönünden istatistiksel olarak önemli derecede (\% 5) farklılık görülmüştür. Araştırmanın birinci yılında nispi yem değeri genotiplerin ortalaması olarak 192.4 iken, ikinci yılda ise NYD 217.0 olarak saptanmıştır. İki yıllık 
ortalama verilere göre; en yüksek NYD istatistiksel olarak birinci grupta yer alan IFVE 248-SEL2785 (218.0) ile HAT-17 (217.1) genotiplerinde belirlenmiştir. Nispi yem değerleri bakımından; Yerel Lice, D-357, MP, HAT-3 ve HAT-13 genotipleri dışındaki diğer genotipler arasındaki farklılık istatistiksel olarak önemsiz çıkmıştır. En düşük NYD 182.9 ile D-357 genotipinde saptanmıştır (Tablo 8).

Araştırmanın birinci yılında IFVE 2698-SEL 2798 genotipi istatistiksel olarak düşük grubu oluşturan nispi yem değerini verirken, çalışmanın ikinci yılında ise aynı genotipin nispi yem değerinde bir miktar artış meydana gelmiş ve istatistiki olarak en yüksek grubu oluşturmuştur. Bunun sonucu olarak, y1l x genotip interaksiyonu istatistiksel olarak \% 5 düzeyinde önemlilik göstermiştir (Tablo 8).

Rohweder ve ark. (1978) tarafindan bildirilen sinıflandırma $[>151=$ en üstün kaliteli, 151-125=1. kalite (çok iyi), $124-103=2$. kalite (iyi), $102-87=3$. kalite (orta), 86-75 (4. kalite (kötü), $<75=5$. kalite (kabul edilemez)] dikkate alındığında, araştırmada ele alınan burçak genotiplerinden "en üstün kaliteli" standardında kaba yem elde edildiği söylenebilir.

Tablo 8. Burçak genotiplerinde belirlenen nispi yem değerlerine ilişkin ortalama değerler

\begin{tabular}{|c|c|c|c|}
\hline \multirow{2}{*}{ Genotipler } & \multicolumn{3}{|c|}{ Nispi yem değeri } \\
\hline & 2014 & 2015 & Ortalama \\
\hline IFVE 248-SEL 2785 & 208.2 d-h & $227.8 \mathrm{a}-\mathrm{c}$ & $218.0 \mathrm{a}$ \\
\hline IFVE 973-SEL 2795 & $201.3 \mathrm{~g}-\mathrm{j}$ & $217.7 \mathrm{a}-\mathrm{g}$ & $209.5 \mathrm{a}-\mathrm{c}$ \\
\hline IFVE 2698-SEL 2798 & $175.7 \mathrm{mn}$ & $236.1 \mathrm{a}$ & 205.9 a-c \\
\hline IFVE 2920-SEL 2801 & $210.5 \mathrm{c}-\mathrm{h}$ & $211.3 \mathrm{c}-\mathrm{h}$ & $210.9 \mathrm{a}-\mathrm{c}$ \\
\hline IFVE 3977-SEL 2802 & $203.4 \mathrm{f}-\mathrm{j}$ & 225.4 a-e & $214.4 \mathrm{ab}$ \\
\hline IFVE 3351-SEL 2804 & $195.8 \mathrm{~h}-1$ & $213.5 \mathrm{~b}-\mathrm{h}$ & $204.6 \mathrm{a}-\mathrm{c}$ \\
\hline Yerel Lice & $177.21-n$ & $226.6 \mathrm{a}-\mathrm{d}$ & $201.9 \mathrm{~b}-\mathrm{d}$ \\
\hline $\mathrm{D}-357$ & $186.0 \mathrm{j}-\mathrm{m}$ & $179.9 \mathrm{k}-\mathrm{n}$ & $182.9 \mathrm{e}$ \\
\hline MP & $189.11-\mathrm{m}$ & 207.5 e-1 & $198.3 \mathrm{~cd}$ \\
\hline HAT-3 & 196.6 h-k & 206.8 e-1 & $201.7 \mathrm{~b}-\mathrm{d}$ \\
\hline HAT-9 & 195.9 h-1 & $216.0 \mathrm{~b}-\mathrm{g}$ & $206.0 \mathrm{a}-\mathrm{c}$ \\
\hline НAТ-13 & $162.1 \mathrm{n}$ & $217.8 \mathrm{a}-\mathrm{g}$ & $190.0 \mathrm{de}$ \\
\hline НАТ-14 & $188.81-\mathrm{m}$ & $220.7 \mathrm{a}-\mathrm{f}$ & $204.7 \mathrm{a}-\mathrm{c}$ \\
\hline HAT-17 & $203.4 \mathrm{f}-\mathrm{j}$ & $230.8 \mathrm{ab}$ & $217.1 \mathrm{a}$ \\
\hline Ortalama & $192.4 \mathrm{~b}$ & $217.0 \mathrm{a}$ & \\
\hline Değişim katsayısı (\%) & & 5.7 & \\
\hline $\mathrm{LSD}_{\mathrm{yll}}$ & & $18.9^{*}$ & \\
\hline LSD genotip & & $13.4^{*}$ & \\
\hline LSD genotip $x$ yll & & $18.9^{*}$ & \\
\hline
\end{tabular}

\section{Sonuçlar}

Bingöl ekolojik koşullarına uygun burçak genotiplerinin belirlenmesi amacıyla 14 farklı burçak genotipi ile yürütülen bu çalışmada; iki yıllık verilere göre, kuru ot ve ham protein verimi ile ADF ve NDF oranları dikkate alındığında, IFVE 248-SEL 2785, IFVE 3977-SEL 2802 ve HAT-14 genotiplerinin öne çıktığı görülmüştür. $\mathrm{Bu}$ genotiplerin verim ve kalite yönünden iyi sonuçlar verdiği dikkate alındığında; IFVE 248-SEL 2785 , IFVE 3977-SEL 2802 ve HAT-14 genotiplerinin Bingöl yöresinde yazlık ara devrede yem bitkileri yetiştiriciliğinde kaba yem üretimine önemli katk1 sağlayacağı düşüncesiyle, ıslah çalışmalarına alınarak üretime dâhil edilmesi önem taşımaktadır.

\section{Kaynaklar}

Açıkgöz, E., 2001. Yem Bitkileri. Uludağ Üniversitesi Güçlendirme Vakfı Yayın No: 182, Vipaş AŞ Yayın No: 58 (3. Bask1), Bursa.

Al, V., Baysal, İ., 1996. Şanlıurfa'da yetiştirilen üç yerel burçak (Vicia ervilia (L.) Willd.) çeşidinde sıra arası mesafenin bazı tarımsal karakterlere etkisi üzerine bir araştırma. Türkiye 3. Çayır Mera ve Yem Bitkileri Kongresi, 17-19 Haziran, Erzurum, s. 274-279.

Andiç, C., Deveci, M., Akdeniz, H., Andiç, N., Terzioğlu, Ö., Keskin, B., Yılmaz, İ., Arvas, Ö., 1996. Van kıraç koşullarına adapte olabilecek burçak (Vicia ervilia (L.) Willd) hatlarının belirlenmesine ilişkin bir araştırma. Türkiye 3. Çayır Mera ve Yem Bitkileri Kongresi, 17-19 Haziran, Erzurum, s. 710-717.

Anonymous, 1990. Official Method of Analysis. Association of Official Analytical 12 Chemists, 15th. Edition, Washington DC, U.S.A, pp. 66-88. 
Ayan, İ., Acar, Z., Başaran, U., Önal Așçı, Ö., Mut, H., 2006. Samsun ekolojik koşullarında bazı burçak hatlarının ot ve tohum verimlerinin belirlenmesi. Ondokuz Mayıs Üniversitesi Ziraat Fakültesi Dergisi, 21(3): 318-322.

Bakoğlu, A., Kökten, K., 2009. Elazığ koşullarında burçakta (Vicia ervilia (L.) Willd.) farklı sıra aralığının verim ve verim unsurları üzerine etkisi. Harran Üniversitesi Ziraat Fakültesi Dergisi, 13(1): 7-12.

Başbağ, M., Biçer, B.T., 2008. Diyarbakır koşullarında bazı burçak (Vicia ervilia (L.) Willd.) 1slah hatlarının tohum verimi ve verim kriterlerinin belirlenmesi. Harran Üniversitesi Ziraat Fakültesi Dergisi, 12(2): 19-25.

Başbağ, M., Gül, İ., 2005. Diyarbakır koşullarında bazı burçak (Vicia ervilia (L.) Willd.) hatlarında verim ve verim unsurlarının belirlenmesi. Harran Üniversitesi Ziraat Fakültesi Dergisi, 9(1): 1-7.

Canbolat, Ö., Bayram, G., 2007. Bazı baklagil tanelerinin in vitro gaz üretim parametreleri, sindirilebilir organik madde ve metabolik enerji içeriklerinin karş1laştırılması. Uludă Üniversitesi Ziraat Fakültesi Dergisi, 21(1): 31-42.

Çaçan, E., Aydın, A., Başbağ, M., 2015. Bingöl Üniversitesi yerleşkesinde yer alan bazı baklagil yem bitkilerine ait kalite özelliklerinin belirlenmesi. Türk Tarım ve Doğa Bilimleri Dergisi, 2(1): 105-111.

Çil, A., Çil, A.N., Yücel, C., Ekiz, H., 2007. GAP Koşullarında bazı burçak (Vicia ervilia (L.) Willd.) hatlarının ot ve tane verimlerinin saptanmasi. Türkiye VII. Tarla Bitkileri Kongresi, 25-27 Haziran, Erzurum, s. 119-122.

Ekiz, H., 1995. Seçilmiş burçak (Vicia ervilia (L.) Willd.) hatlarının kışa dayanıklılığ ile tohum verimi ve bazı bitkisel özellikleri. Ankara Üniversitesi Ziraat Fakültesi Yayınları, No: 1405, Bilimsel Araştırma ve İncelemeler: 783, Ankara.

Gonzalez, J., Andres, S., 2003. Rumen degradability of some feed legume seeds. Animal Research, 52: 17-25.

Hoy, M.D., Moore, K.J., George, J.R., Brummetr, E.C., 2002. Alfalfa yield and quality as influenced by establishment method. Agriculture Journal, 94: 6571.

İriadam, M., Avcı, M., 2003. Hindi rasyonlarına değişik oranlarda katılan burçağın (Vicia ervilia (L.) Willd.) performans, bazı hematolojik ve biyokimyasal parametreler üzerindeki etkisi. Harran Üniversitesi Ziraat Fakültesi Dergisi, 7(3-4): 37-43.

Kacar, B., 1972. Bitki ve Toprağın Kimyasal Analizleri, II. Bitki Analizleri. Ankara Üniversitesi Ziraat Fakültesi Yayınları, No: 453, Uygulama Kılavuzu No: 155 , Ankara.

Kalaycı, Ş., 2005. SPSS Uygulamalı Çok Değişkenli İstatistik Teknikleri. Asil Yayın Dağıtım, Ankara.

Karaköse, N., 2018. Bingöl ekolojik koşullarında bazı yem bezelyesi (Pisum arvense L.) genotiplerinin kışlık ekimde verim ve verim öğelerinin belirlenmesi. Yüksek lisans tezi, Bingöl Üniversitesi Fen Bilimleri Enstitüsü, Bingöl.
Karaşahin, M., 2014. Kaba yem kaynağ 1 olarak hidroponik arpa çimi üretiminde kuru madde ve ham protein verimleri üzerine farklı uygulamaların etkileri, Süleyman Demirel Üniversitesi Ziraat Fakültesi Dergisi, 9(1): 27-33.

Morrison, J.A., 2003. Hay and pasture managment, chapter 8. extension educator, crop systems rock ford extension center. (http://iah.aces.uiuc.edu/pdf/ Agronomy_HB/08chapter.pdf), (Erişim tarihi: 10.06.2018).

Osmanl1, Ş., 2014. Kayseri ekolojik şartlarında bazı burçak (Vicia ervilia (L.) Willd.) hatlarının verim ve verim unsurları ile tanelerinin kimyasal kompozisyonun belirlenmesi. Yüksek lisans tezi, Erciyes Üniversitesi Fen Bilimleri Enstitüsü, Kayseri.

Özköse, A., 2003. Burçak (Vicia ervilia (L.) Willd.)'ta ekim zamanının verim ve verim öğeleri üzerine etkisi. Yüksek lisans tezi, Ankara Üniversitesi Fen Bilimleri Enstitüsü, Ankara.

Özyazıcı, M.A., Manga, İ., 2000. Çarşamba Ovası sulu koşullarında yeşil gübre olarak kullanılan bazı baklagil yembitkileri ile bitki artıklarının kendilerini izleyen misır ve ayçiçeğinin verim ve kalitesine etkileri. Türk Tarım ve Ormancllık Dergisi, 24: 95103.

Rohweder, D.A., Barnes, R.F., Jorgensen, N., 1978. Proposed hay grading standards based on laboratory analyses for evaluating quality. Journal of Animal Science, 47(3): 747-759.

Sadeghi, G.H., Pourreza, J., Samei, A., Rahmani, H., 2009. Chemical composition and some anti nutrient content of raw and processed bitter vetch (Vicia ervilia (L.) Willd) seed for use as feding stuff in poultry diet. Tropical Animal Health and Production, 41: 85-93.

Seifdavati, J., Taghizadeh, A., Janmohammadi, H., Rafat, S.A., Alijani, S., 2013. In situ ruminal degradability and in vitro intestinal digestibility of crude protein from some minor legume species. African Journal of African Journal of Biotechnology, 12(17): 22932302.

Seydoşoğlu, S., Saruhan, V., Kökten, K., 2015. Diyarbakır ekolojik koşullarında bazı burçak (Vicia ervilia (L.) Willd) genotiplerinin verim ve verim unsurlarının belirlenmesi, Gaziosmanpaşa Üniversitesi Ziraat Fakültesi Dergisi, 32(2): 107115.

Turan, N., Özyazıcı, M.A., Yalçın Tantekin, G., 2015. Siirt ilinde çayır mera alanlarından ve yem bitkilerinden elde edilen kaba yem üretim potansiyeli. Türkiye Tarımsal Araştırmalar Dergisi, 2(1): 69-75.

Türk, M., Albayrak, S., Yüksel, O., 2011. Effect of seeding rate on the forage yields and quality in pea cultivars of differing leaf types. Turkish Journal of Field Crops, 16(2): 137-141

Uzun, B., 2008. Tokat ekolojik şartlarında bazı burçak (Vicia ervilia (L.) Willd.) hatlarının verim ve verim öğelerinin belirlenmesi. Yüksek lisans tezi, Gaziosmanpaşa Üniversitesi Fen Bilimleri Enstitüsü, Tokat. 